\title{
Entrepreneurial attitudes: A distinction between two professional groups
}

\author{
R. van Wyk* \& A.B. Boshoff \\ Department Human Resources Management. \\ University of Pretoria, Pretoria 0001, Republic of South Africa \\ rvanwyk@hakuna.up.ac.za
}

Received January 2004

\begin{abstract}
This study investigates discrimant ability of the Entrepreneurial Attitude Orientations Scale of 365 individuals practicing in two mutually exclusive professions (pharmacists $\mathrm{N}=200$ and accountants $\mathrm{N}=175$ ) on the profiles of Holland's hexagon of occupational groups. Anova was performed with the EAOS sub-and total scales as dependent variables and entrepreneurial and non-entrepreneurial profiles as independent variables. Some discriminance by means of Tukey's Range Test and interaction through LS-means was found between the two professions and employment status of individuals. Implications for management are indicated.
\end{abstract}

*To whom all correspondence should be addressed.

\section{Introduction}

Enquiries into the economic functioning of many countries have indicated successful entrepreneurship as a major component of a healthy market economy and important source of job creation (Hisrich \& Peters, 1998; Jackson \& Rodkey, 1994; Jennings, 1994; Kroon, 2002; North, 2002; Timmons, 1994; Van Aardt \& Van Aardt, 1997). Encouragement of entrepreneurial activity in South Africa is important in the light of many economic challenges the country is currently confronted with (Gouws, 2002; Kroon, 2002; Kroon \& Meyer, 2001; Niewenhuizen \& Kroon, 2002; North, 2002). The presence of entrepreneurial thinking in existing organizations would also lead to a competitive advantage (Covin \& Miles, 1999) and improved financial performance (Goosen, De Coning \& Smit, 2002). Birkinshaw (1999) indicates that corporate entrepreneurial behaviour is related to mainly individual, organisational and environmental factors. Jacobs and Kruger (2001) indicate the need of developing a strategic management approach for the processing of corporate entrepreneurship. It is therefore to the benefit of management to identify individual entrepreneurial behaviour which will lead to pro-activeness in new business venturing.

In order to identify entrepreneurial characteristics, many studies concentrated on the isolation of biographic variables and personality traits as entrepreneurial characteristics. No consistent pattern of biographic and personality entrepreneurial features were verified, leading to criticism in the literature by the end of the 1980's of a lack of consistency in findings (Gartner, 1988) and a deficiency in the depiction of a clear paradigm (Bygrave, 1989). Hisrich and Peters (1998) argued that there is no established personality profile representing the ideal entrepreneur. A call was made for new directions of investigation into entrepreneurship.
Robinson, Stimpson, Heufner and Hunt (1991) directed the exploration of attitudes as an alternative avenue of investigating entrepreneurship. These authors refer to entrepreneurial behaviour as attitudes formed through the strength of an individual's subjective association and formed values towards certain attributes (Ajzen \& Fishbein, 1977). An attitude is the representation of a summarised perception of a psychological object, experienced as advantageousdetrimental, pleasing-unpleasant, or beneficial/harmful (Ajzen \& Fishbein, 1977). Robinson, et al. (1991), however, contemplate that an attitude is not only one dimensional, as indicated by Ajzen and Fishbein (1977), but rather threedimensional, as originally theorised by Allport (1935), namely the conglomeration of affective (feelings) and cognitive (beliefs/thoughts) that lead to conative behavioural intentions.

Robinson, et al. (1991) adopted this attitudinal theoretical approach explaining the development of behaviour, as a potential method of investigating entrepreneurial orientated individuals. Four important entrepreneurial attitudes were identified from the literature, namely Achievement, SelfEsteem, Personal Control and Innovation. An instrument was developed to measure these characteristics, called the Entrepreneurial Attitude Orientation Scale (EAOS) (Robinson, et al., 1991). The four attitude sub-scales were described as:

1. Achievement, in creating a business.

2. Innovation, by acting upon business incentives.

3. Perception of personal control and influence over business incentives.

4. Perceived self-esteem as indication of self-evaluated competence in business affairs. 
Each of the sub-scales is reported to be the product of the three theoretical attitudinal behavioural components of Cognition (beliefs and thoughts), Affection (positive or negative conviction) and Conative Behaviour (intentions and actions), represented in Figure 1.

Robinson et al. (1991), verified the predictive/discriminatory validity of EAOS, though no standardization on the construct and content validity of the questionnaire was done. These authors report that the scale significantly discriminated between non-entrepreneurs and entrepreneurs in a USA sample, on the four sub-scales of achievement, self-esteem, personal control and innovation. The application of the scale on an Indian sample of entrepreneurs $(\mathrm{N}=97)$ and white-collar workers $(\mathrm{N}=101)$ indicated the discriminatory ability of only the personal control scale (Stimpson, Heufner, Narayanan, Shanthakumar, 1993). The argument followed that because the scale showed low discriminance in the India sample, it could be a probable indication of low portability. In the same study on a USA sample of 151 entrepreneurs and 47 managers, analyses indicated that entrepreneurs were distinguished from non-entrepreneurs on the three subscales of innovation, achievement and personal control but not the entrepreneurial self-esteem sub-scale. EAOS did not discriminate between consumer entrepreneurs and consumer non-entrepreneurs in a study of 293 individuals, which is seen as an indication that entrepreneurial attitudes of entrepreneurs in trade and industry are probably also present in non-business entrepreneurs (Heufner \& Hunt, 1994).

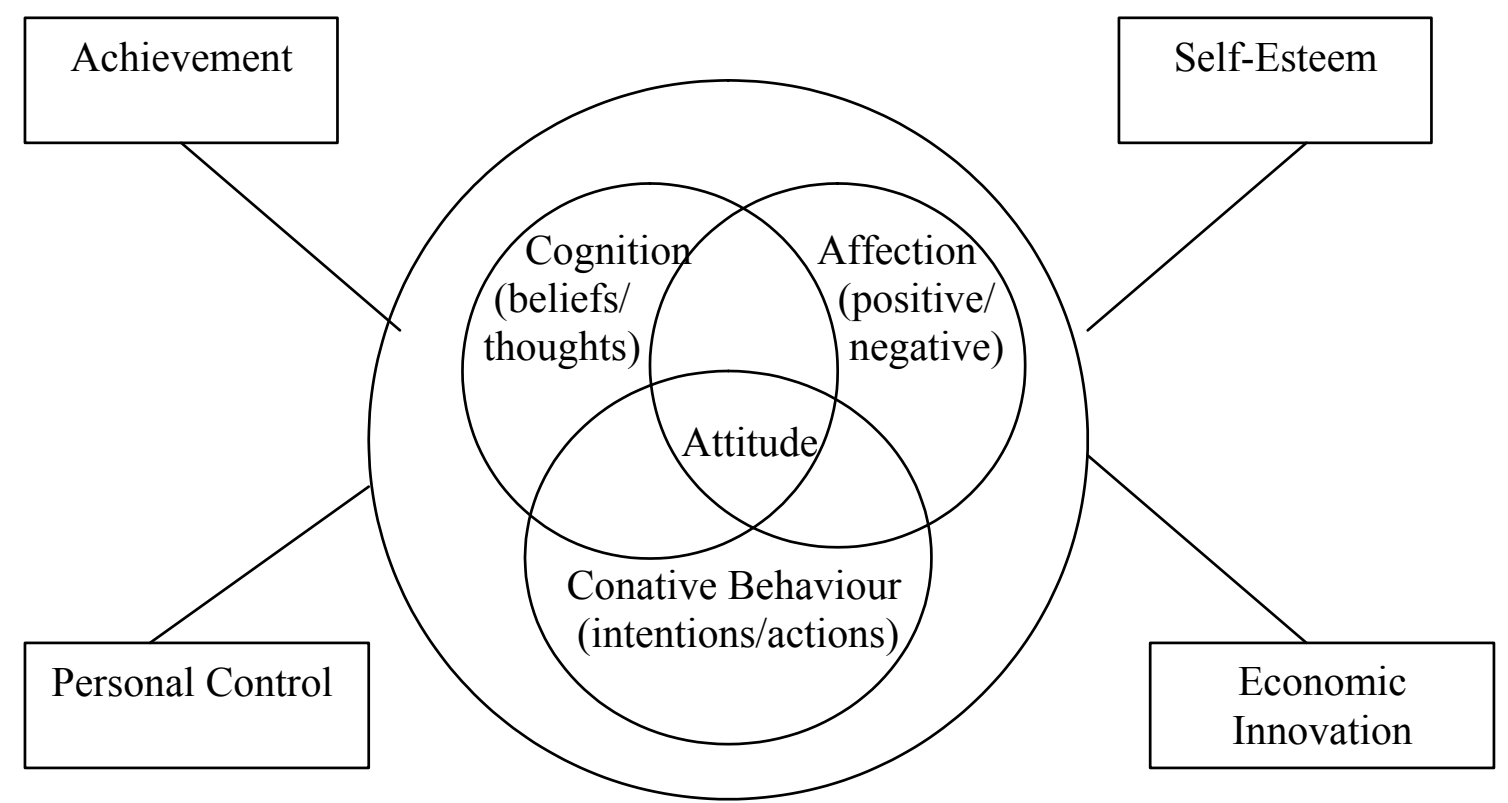

Figure 1: Attitudes consisting achievement, self-esteem, personal control and innovation in combination with underlying cognition, affection and conations

Other studies reflect on the discriminatory validity of the EAOS: In a study by Boshoff and Scholtz (1995) on 110 entrepreneurs, 113 engineers and 76 managers, EAOS discriminated between entrepreneurs and non-entrepreneurs, entrepreneurs in manufacturing and individuals in retail and service businesses by means of MANOVA. Further analyses of the Boshoff and Scholtz (1995) data by Hoole and Boshoff (1997) by means of ANOVA and Tukey's Range Test indicated significant differences between entrepreneurs opposed to engineers, and engineers opposed to managers on the three EAOS sub-scales of innovation, self-esteem and achievement. Further investigation by means of MANOVA indicated overall significant differences between entrepreneurs and engineers on three EAOS sub-scales (Innovation, Self-esteem and Achievement) as well as total EAOS scale. Step-wise Discriminant Analyses was performed, indicating satisfactory discriminatory confirmation of the three identified sub-scales.
Kruger, Van Wyk \& Boshoff (2002), report significant differences on four of the EAOS sub-scales by means of ANOVA followed by the Tukey's Range Test in a sample of sales representatives, administrative personnel and engineers $(\mathrm{N}=192)$. The Achievement sub-scale indicated sales representatives and administrative personnel scoring higher than engineers. On the Personal Control sub-scale sales representatives scored higher than administrative personnel and engineers, while administrative personnel showed a higher score than engineers. The Innovation sub-scale indicated sales representatives and administrative personnel scoring higher than engineers. The Self-Esteem sub-scale indicated sales representatives scoring lower than administrative personnel and engineers.

Seeing in the light of the importance of entrepreneurial activity for the economic growth of a country and a business, management it could be beneficial for management to be able to identify individuals with entrepreneurial orientations. Should the entrepreneurial characteristics as measured by the EAOS distinguish 
between careers in two mutually exclusive profiles (entrepreneurial and non-entrepreneurial) represented by the Holland's Hexagon Model (Holland, 1985) (see Figure 2), this instrument can be used to the benefit of organisations. It is further questioned whether different occupational groups (private practitioners or employees) would share different or similar entrepreneurial attitudes as measured by the EAOS.

\section{Aim}

The first aim of the present study was to determine whether the EAOS could distinguish between two mutually exclusive profiles on Holland's Hexagon (1985) of occupational groups (entrepreneurial and non-entrepreneurial) represented by members from two different professional occupations. The second aim was to determine whether the EAOS could differentiate between individuals working as private practitioners from those who functioned as employees in organizations.

\section{Method}

\section{Participants}

The sample consisted of two groups of professionals $(\mathrm{N}=375)$, from mutually exclusive profiles on Holland's Hexagon (1985). Two hundred professionally registered pharmacists represented the highly investigative, moderately artistic and slightly realistic half of the hexagon, while the 175 accountants represented the highly conventional, moderately enterprising and slightly social opposite half of the hexagon. The pharmacists had a mean age of 39,46 years $(\underline{\mathrm{SD}}=12,70)$ and accountants a mean age $=44,1$ years, $\underline{\mathrm{SD}}$ $=11,95)$. The gender division consisted of 221 males and 154 females. The home language of the participants were indicated as $221(56,3 \%)$ English speakers and $158(42,1 \%)$ Afrikaans speakers, with a small number of Venda $(\mathrm{N}=1)$, Zulu $(\mathrm{N}=2)$ and North Sotho $(\mathrm{N}=2)$ speakers. A distinction was made between private practitioners $(\mathrm{N}=169 ; 45,1 \%)$ and employees $(\mathrm{N}=201 ; 53,6 \%)$ with $\mathrm{N}=5(1,3 \%)$ as unknown.

\section{Measuring instrument}

The questionnaire consisted of the EAOS Robinson et al. (1991), measuring Entrepreneurial Attitudes and enquiries concerning biographic information. The EAOS consisted of 75 items measured on a 10-point Likert scale. The responses on the scale varied between ' 1 ', strongly disagree, ' 5 ', slightly disagree, ' 6 ' slightly agree, and ' 10 ' strongly agree. Alpha coefficients of $0,84,0,73,0,70$ and 0,70 were reported for the four factors of Achievement, Innovation, Self-Esteem and Personal Control respectively. Test-retest reliabilities were reported as respectively $0,76,0,76,0,71$ and 0,85 .

\section{Procedure}

Random stratified sampling was performed, on two mutually exclusive professions, namely pharmacists and accountants, representing entrepreneurial and nonentrepreneurial profiles on the Holland Hexagon. A mail distribution of the questionnaires 1100 in Gauteng and 100 in the Western Cape led to the reception of 418 completed questionnaires. Should any of the psychometric instruments not have had a response on one or more of the items, the total questionnaire was left out of the analyses. Therefore only 375 questionnaires were used for the statistical analyses.

Non-entrepreneurial profile (represented by the pharmacists profession)

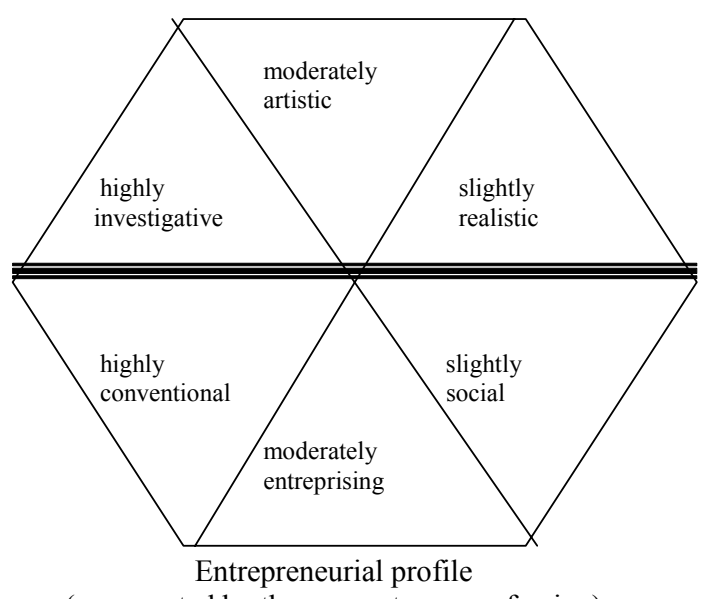

(represented by the accountancy profession)

Figure 2: Holland's (1985) hexagon of occupational groups

Factor Analyses was done to confirm construct validity and limit error variance measurements as far as possible (Cavusgil \& Das, 1997). Principal Factor Analysis was used for this purpose with Direct Quartimin rotation. This was followed by Confirmatory Factor Analysis to assess the quality of fit between the measurement model and the data. The results indicated three instead of four factors, with Achievement/Personal Control loading on one factor. Thirteen of the original items of the questionnaire did not load satisfactorily on any of the factors in the finally preferred three-factor solution. The respective Alpha coefficients of the three identified factors were: attitude towards Economic Innovation $(0,90)$, Achievement/Personal Control $(0,80)$ and Self-Esteem $(0,77)$. The three factors contained 29, 21 and 12 items respectively.

\section{Statistical analysis}

Analysis of Variance was done to determine the relationships between Entrepreneurial Attitudes sub- and total scales as dependent variables and occupational profile (represented by accountants and pharmacists), as well as occupational status as independent variables. The significance of these relationships was further investigated by means of Tukeys' range test and the t-test on the LS means.

\section{Results}

The scores of the different ANOVAS with the Entrepreneurial Attitude sub- and total scores as dependent variables are reported in Tables 1 to 4 . The result of each table is discussed in relation with the Tukey's range test and 
the t-test on the LS-means, estimating the marginal means of the scores on the responses of the individuals.

Table 1: Results of analysis of variance with the economic innovation sub-scale as dependent variable

\begin{tabular}{l|c|c|c}
\hline \multicolumn{1}{c|}{ Independent variable } & F & df & P > F \\
\hline $\begin{array}{l}\text { Entrepreneur (accountant)/Non- } \\
\text { entrepreneur (pharmacist) }\end{array}$ & 6,64 & 1 &, 0104 \\
\hline Private practice/employee & 1,13 & 1 &, 2886 \\
\hline $\begin{array}{l}\text { Entrepreneur (accountant)/Non- } \\
\text { entrepreneur (pharmacist) in interaction } \\
\text { with private practitioner/employee }\end{array}$ & 9,50 & 1 &, 0022 \\
\hline
\end{tabular}

The ANOVA in Table 1 indicates a significant difference at $\mathrm{p} \leq 0,05$ in the relationship between the Economic Innovation sub-scale and the entrepreneurial/nonentrepreneurial profile as well as the interaction between entrepreneurial/non-entrepreneurial and employed or in private practice. The Tukey's range test and LS-means indicate the entrepreneurial profile represented by accountants scoring significantly higher than individuals representing the non-entrepreneurial profile. The interaction between entrepreneurial/non-entrepreneurial individuals employed or in private practice indicates that employed pharmacists (non-entrepreneurs, not in their own business) score significantly lower on the economic innovation subscale than non-entrepreneurs (pharmacists) in private practice and entrepreneurs (accountants) both employed and in private practice.

Table 2: Results of Analysis of Variance with the Achievement/Personal Control Sub-Scale as Dependent Variable

\begin{tabular}{l|r|r|r}
\hline \multicolumn{1}{c|}{ Independent variable } & F & df & P > F \\
\hline $\begin{array}{l}\text { Entrepreneur (accountant)/Non- } \\
\text { entrepreneur (pharmacist) }\end{array}$ &, 50 & 1 &, 4809 \\
\hline Private practice/employee &, 20 & 1 &, 6545 \\
\hline $\begin{array}{l}\text { Entrepreneur (accountant)/Non- } \\
\text { entrepreneur (pharmacist) in interaction } \\
\text { with private practitioner/employee }\end{array}$ & 1,43 & 1 &, 2325 \\
\hline
\end{tabular}

The ANOVA in Table 2 indicate no significant differences with the Achievement/Personal Control sub-scale as dependent variable, and entrepreneurs/non-entrepreneurs either employed or in private practice as independent variables at $\mathrm{p} \leq 0,05$.

Table 3: Results of analysis of variance with the entrepreneurial self-Esteem sub-scale as dependent variable

\begin{tabular}{l|r|r|c}
\hline \multicolumn{1}{c|}{ Independent variable } & F & df & P > F \\
\hline $\begin{array}{l}\text { Entrepreneur (accountant)/Non- } \\
\text { entrepreneur (pharmacist) }\end{array}$ & 1,05 & 1 &, 3057 \\
\hline Private practice/employee & 10,14 & 1 &, 0016 \\
\hline $\begin{array}{l}\text { Entrepreneur (accountant)/Non- } \\
\text { entrepreneur (pharmacist) in interaction } \\
\text { with private practitioner/employee }\end{array}$ & 3,06 & 1 &, 0811 \\
\hline
\end{tabular}

Table 3 indicates at $p \leq 0.05$ that with Self-Esteem Entrepreneurial Attitude as dependent variable, a significant difference was indicated on the private practitioner/employee independent variables. The Tukey's ranges test and LS-means showed the direction of employees scoring higher on the entrepreneurial self-esteem sub-scale than private practitioners.

Table 4: Results of analysis of variance with the entrepreneurial attitude total as dependent variable

\begin{tabular}{l|c|c|c}
\hline \multicolumn{1}{c|}{ Independent variable } & F & df & P > F \\
\hline $\begin{array}{l}\text { Entrepreneur (accountant)/Non- } \\
\text { entrepreneur (pharmacist) }\end{array}$ & 1,50 & 1 &, 2214 \\
\hline Private practice/employee & 0,29 & 1 &, 5890 \\
\hline $\begin{array}{l}\text { Entrepreneur (accountant)/Non- } \\
\text { entrepreneur (pharmacist) in interaction } \\
\text { with private practitioner/employee }\end{array}$ & 4,49 & 1 &, 0348 \\
\hline
\end{tabular}

The ANOVA of Table 4 indicates that with the Entrepreneurial Attitude Total as dependent variable, a significant difference existed in the independent variables at $\mathrm{p} \leq 0.05$ in the interaction between entrepreneur/nonentrepreneur either employed or in private practice. The Tukey's ranges test and LS-means scores within the independent variables however indicated no significant differences.

\section{Discussion}

In the application of ANOVA with the three Entrepreneurial Attitude sub-scales as well as the total as dependent variables, and entrepreneurial/non-entrepreneurial profiles of individuals either employed or in private practice, indicated some significant differences between these groups.

The Economic Innovation sub-scale clearly discriminated between the entrepreneurial and non-entrepreneurial profiles as well as in interaction with employed or in private practice. The discriminance of the Economic Innovation sub-scale was also indicated by all the previous studies (Heufner \& Hunt, 1994; Hoole \& Boshoff, 1997; Kruger et $a l ., 2002)$. It seems that the Economic Innovation factor could be applied useful in management to identify individuals needed to act upon business incentives. Goosen, et al. (2002), Jacobs and Kruger (2001), as well as Adonisi (2004), indicated that Economic Innovation is imperative for organisations that want to depart from conventional ideas towards uniqueness. Goosen, et al. (2002), argues that organisations should put systems into operation that are supportive of innovative behaviour.

The investigation of the Achievement/Personal Control subscales did not indicate any significant differences between the entrepreneurial/non-entrepreneurial profiles, either in private practice or employed. It is however important to notice that the items on the Achievement and Personal Control sub-scales were intended for individuals who have created their own business and had influence over their business incentives respectively. Biographic variables unfortunately did not differentiate between individuals that created their own businesses. Previous studies however 
discriminated well on the Achievement and Personal Control sub-scales (Heufner \& Hunt, 1994; Hoole \& Boshoff, 1997; Kruger et al. 2002). Alternatively the interpretation is made that individuals both in the entrepreneurial and non-entrepreneurial domains, presented similar Achievement and Personal Control orientations.

The findings concerning the entrepreneurial Self-Esteem sub-scale is surprising, with the indication that employees scored higher than private practitioners in the current study and administrative personnel higher than in entrepreneurs the Kruger et al. (2002) study. This is an indication of higher self-evaluated competence in business affairs for employed individuals than individuals owning their own businesses or in private practice. The lower risks factors that employees are exposed to could be the reason for this phenomenon. This trait can also be used by management to identify individuals scoring high on entrepreneurial SelfEsteem sub-scale in a strategy to improve corporate entrepreneurship (Jacobs \& Kruger, 2001). Due to the fact that employees do not work with their own money and thus have a different appetite for risk, care should be taken that initiatives remain within reasonable risk boundaries.

The results indicate that the discriminatory validity of the Economic Innovation as well as Self-Esteem sub-scales of the EAOS is portable in the South African situation in both the current and the Kruger et al. (2002) studies. Organisations that promote corporate entrepreneurship could use the EAOS to identify individuals strong at Economic Innovation and Self-Esteem orientations to take part in brainstorming for new venture creations. On the other hand individuals scoring low on any of the sub-scales could be trained and encouraged into more innovative thinking, as it is indicated by Rosenberg and Hovland (1966) that change towards attitudes can be initiated by influencing cognition, affect, and conation. Ajzen (2001) sees the alternation of attitudes as viable due to the dynamic interaction process through which attitudes are formed, which is less stable than personality traits. The promotion of these attitudes in the education of entrepreneurship is also imperative (Gouws, 2002; Kroon, 2002; Kroon \& Meyer, 2001; Niewenhuizen \& Kroon, 2002; North, 2002).

The discriminatory potential of this instrument is an indication that it could lead to deeper insights of the behaviour of entrepreneurs. Detection of the entrepreneurial Innovative and Self-Esteem attitudes can be used by organisations to identify individuals in the championing of a creative corporate intrepreneurial culture as contemplated by Jacobs and Kruger (2001) as well as Goosen, et al. (2002). Training in the development of the entrepreneurial attitudes of Economic Innovation and Entrepreneurial Self-Esteem could enhance entrepreneurial activity, beneficial to the individual, businesses and society, especially in the South African society with an unemployment rate of $32.6 \%$ (Gouws, 2002).

Certain limitations are indicated concerning the current study. This study did not define individuals that created their own businesses, but rather individuals in two exclusive professions representative of the mutually exclusive entrepreneurial and non-entrepreneurial profiles of the
Holland (1985) Hexagon. Future studies could concentrate more on differences in samples of true entrepreneurs and other categories of non-entrepreneurs in order to gain a clearer picture between these groups. Research could also investigate the possible relationship between the EAOS characteristics and Holland occupational categories. The viability of teaching attitudinal entrepreneurial characteristics in the development of a successful entrepreneurial mind shift should be investigated.

\section{Conclusion}

The identified entrepreneurial attitudes should not only be used in businesses to improve corporate entrepreneurship (Covin \& Miles, 1999; Goosen, et al., 2002; Gouws, 2002; Kroon, 2002; Kroon \& Meyer, 2001; Niewenhuizen \& Kroon, 2002; North, 2002), but also applied in educational systems to advance the proficiency and propensity towards entrepreneurial behaviour (Gouws, 2002; Kroon, 2002; Kroon \& Meyer, 2001; Niewenhuizen \& Kroon, 2002; North, 2002).

\section{References}

Adonisi, M. 2004. 'The relationship between corporate entrepreneurship, market orientation, organisational flexibility and job satisfaction'. Unpublished doctoral thesis, University of Pretoria.

Ajzen, I. 2001. 'Nature and operation of attitudes', Annual Review of Psychology, 52:27-58.

Ajzen, I. \& Fishbein, M. 1977. 'Attitude-behaviour relations: a theoretical analysis and review of empirical research', Psychological Bulletin, 84(5):888-918.

Allport, G.W. 1935). 'Attitudes'. In Murchison, C. (Ed.). Handbook of social psychology. Worcester, MA: Clark University, pp. 798-884.

Birkinshaw, J. 1999. 'The determinants and consequences of subsidiary initiative in multinational corporations', Entrepreneurship Theory and Practice, 24(1):9-37.

Boshoff, A.B. \& Scholtz, C.P.T. 1995. 'Measuring attitudes as a way of differentiating entrepreneurs', South African Journal of Economic and Management Sciences, 16:1-11.

Boshoff A.B., Theron S.W. \& Schutte J.L. 1998. 'Prediction of the success level of entrepreneurial ventures by means of biographical and business variables in a third world setting,' South African Journal of Economic and Management Science, 1(3):348-361.

Bygrave, W.D. 1989. 'The entrepereneurship paradigm (1): a philosophical look at its research methodologies', Entrepreneurship Theory and Practice, Fall, 14:7-26.

Cavusgil, T.S. \& Das, A. 1997. 'Methodological issues in empirical cross-cultural research: a survey of the management literature and a framework', Management International Review, 37(1):71-62. 
Covin, J.G. \& Miles, M.P. 1999. 'Corporate entrepreneurship and the pursuit of competitive advantage', Entrepreneurship Theory and Practice, 23(3):47-64.

Gartner, W.B. 1988. "Who is an entrepreneur?" Is the wrong question' American Journal of Small Business, 12(4):11-32.

Gouws, E. 2002. 'Entrepreneurship education: implications for teacher training', South African Journal for Higher Education, 16(2):41-48.

Goosen, C.J., De Coning, T.J. \& Smit, E.v.d.M. 2002. 'Corporate entrepreneurship and financial performance: The role of management', South African Journal of Business Management, 33(4):21-27.

Holland, J.L. 1985. Making vocational choices: A theory of vocational personalities and work environments. $2^{\text {nd }}$ Edition. Englewood Cliffs, NJ: Prentice-Hall.

Hoole, C. \& Boshoff A.B. 1997. 'Measurement qualities of the entrepreneurial attitude orientation scale when used inter-culturally', South African Journal of Economic and Management Sciences, Fall, 21:1-25.

Huefner, J.C. \& Hunt, H.K. 1994. 'Broadening the concept of entrepreneurship: comparing business and consumer entrepreneurs', Entrepreneurship Theory and Practice, Spring :61-75.

Hisrich, R.D. \& Peters, M. P. 1998. Entrepreneurship. 4th Edition. Boston: Irwin McGraw-Hill.

Jacobs, H. \& Kruger, S. 2001. 'Establishing an intrapreneurial orientation as strategy: a framework for implementation', Acta Commercii, 1:1-11.

Jackson, J.E. \& Rodkey, G.R. 1994. 'The attitudinal climate for entrepreneurial activity', Public-Opinion-Quarterly, 58(3):358-380.

Jennings, D.F. 1994. Multiple perspective of entrepreneurship: text, readings and cases. Cincinnatti: South Western Publishing Co.

Kroon, J. 2002. "n Strategie vir entrepreneurskapontwikkeling in Suid-Afrika,' Tydskrif vir Geesteswetenskappe, 42(3):215-223.

Kroon, J. \& Meyer, S. 2001. 'The role of entrepreneurship education in career expectations of students', South African Journal of Higher Education, 15(1):47-59.

Kruger, B.J., Van Wyk, R. \& Boshoff, A.B. 2002. 'Entrepreneurial attitudes in different occupational and organizational groupings'. Article submitted to the Journal of the Southern Africa Institute for Management Scientists.

Niewenhuizen, C. \& Kroon, J. 2002. 'Identification of entrepreneurial success factors to determine the content of entrepreneurship subjects', South African Journal of Higher Education, 16(3):157-166.
North, E. 2002. 'A decade of entrepreneurship education in South Africa', South African Journal of Education, 22(1):24-27.

Robinson, P.B., Stimpson, D.V., Heufner, J.C. \& Hunt, K.N. 1991. 'An attitude approach to the prediction of entrepreneurship', Entrepreneurship: Theory and Practice, 15(4):13-31.

Rosenberg, M.J. \& Hovland, C.I. (Eds.). 1966. Attitude organization and change: An analysis of consistency among attitude components. Oxford, England: Yale U. Press.

Stimpson, V.S., Huefner, J.C., Narayanan, S. \& Shanthakumar, D. 1993. 'Attitudinal characteristics of male and female entrepreneurs of the United States and India', Psychological Studies, 38(2):64-68.

Timmons, J.A. 1994. New venture creation: Entrepreneurship for the $21^{\text {st }}$ century. Homewood Ill.: Irwin.

Van Aardt, J \& Van Aardt, C. 1997. Entrepreneurship and new venture management. Johannesburg: International Thomson Publishing. 